\title{
ADVANCING SUSTAINABLE DEVELOPMENT THROUGH ENVIRONMENTAL COMMITMENT OF APPAREL PRODUCERS
}

\author{
Maria Gheorghița, ORCID: 0000-0002-2177-3497, \\ Ala Oberșt ${ }^{*}$, ORCID: 0000-0002-8295-7695 \\ Technical University of Moldova, 168 Stefan cel Mare Blvd., MD-2004, Chisinau, Republic of Moldova \\ "Corresponding author: Ala Oberst, ala.oberst@emin.utm.md
}

Received: 11. 15. 2020

Accepted: 01. 20. 2021

\begin{abstract}
The sustainability of the enterprise seen in contemporary society is based on the assumption that the economy and the environment must be reconciled and connected through a new and complex approach. In a similar perspective, this article reflects the activity of apparel producers from the Republic of Moldova, mainly oriented towards foreign markets. Thus, the development models of apparel producers must focus on the integration of environmental aspects, based on sustainable growth. In this article, the authors propose to empower producers to adopt the environmental commitment by establishing environmental policy and strategies within an environmental management system. Therefore, these commitments should among the priorities of long-term development business strategies to ensure increased efficiency, nature protection and the achievement of sustainability goals. Environmental actions are essential in creating the image of a responsible producer concerned with the quality of life of future generations.
\end{abstract}

Key words: sustainability, wearing apparel manufacturers, environment, European Union, environmental management system, corporate ecology, policy, commitment, global competitiveness.

Rezumat. Sustenabilitatea întreprinderii privită în societatea contemporană este fundamentată pe asumpția că economia și mediul trebuie reconciliate și unite printr-o abordare nouă și complexă. Într-o abordare similară, în prezentul articol se reflectă activitatea întreprinderilor de fabricare a articolelor de îmbrăcăminte din Republica Moldova orientate preponderent spre piețele externe. În consecință, modelele de dezvoltare a întreprinderilor de confecții trebuie focusate pe integrarea aspectelor de mediu în afacerile realizate, bazat pe creșterea sustenabilă. În prezentul articol autorii propun responsabilizarea producătorilor prin asumarea angajamentului de mediu prin stabilirea politicilor și strategiilor de protecție a mediului și aplicarea acestora în cadrul unui sistem de management al mediului. Prin urmare, aceste angajamente trebuie să se regăsească printre prioritățile strategiilor de dezvoltare pe termen lung astfel încât să se asigure creșterea eficienței, protejarea naturii și îndeplinirea dezideratelor de sustenabilitate. Acțiunile ecologiste sunt esențiale în crearea imaginii de producător responsabil preocupat de calitatea vieții generațiilor viitoare.

Cuvinte-cheie: sustenabilitatea, întreprinderile de fabricare a articolelor de îmbrăcăminte, mediul înconjurător, Uniunea Europeană, sistem de management de mediu, ecologismul corporatist, politica, angajamentul, competitivitatea globală. 


\section{Introduction}

Today, we live in a society that increasingly questions the sustainability of its own models - economic and social. The sustainability of the enterprise seen in contemporary society admits that corporate growth and economic efficiency are important, but they require adaptation to the objectives of sustainable development - environmental protection.

The theme of sustainability and sustainable development have become increasingly relevant because of the following reasons [1 - 2]:

- population growth, urbanization and urban pollution;

- the increase of industrialization, which is the cause of the deficit of essential resources, generating a negative impact on the natural environment and social changes. The increase of industrialization is caused both by the increasing demand to meet the needs of a growing population, as well as the increasing needs for consumption;

- the development of middle classes with high levels of consumption;

- the phenomena of global warming and climate change generated by the increase of pollution levels (especially greenhouse gas emissions), which lead to an increase in the number and frequency of natural disasters, and to health and adaptation problems of the population.

The industrial production has a direct impact on the environment. Increased production leads to increased energy, water and raw materials consumption, generating higher levels of waste and pollution of soil, water and air, which in combination with the use of high-risk materials cause negative effects on the health of the population and limit people's and other species' access to clean water, thus presenting a threat for the biodiversity.

Apparel manufacturing in the Republic of Moldova registers an annual increase in the value of manufactured production. Over $70 \%$ of the manufactured production is intended for foreign markets, which impose their own requirements on their business partners. Some of these requirements imply the conceptualization and the implementation of the technological processes for apparel manufacturing in compliance with all laws, regulations, and environmental standards, including those related to waste coming from production facilities. In addition, apparel producers must act in a socially and environmentally responsible manner and show due diligence in their activities to avoid adverse effects on the environment, people, and protect the brand and reputation of the foreign client.

Foreign clients encourage their partner apparel manufacturers from the Republic of Moldova to make ongoing efforts in ensuring optimizations for sustainability and commit to environmental protection, while complying with such requirements as:

- having a valid environmental permit;

- holding and displaying the environmental policy to address the environmental impact;

- monitoring the impact of the apparel manufacturer's economic activity on the environment;

- setting and approving objectives on environmental issues related to reduction in water consumption and waste disposal, as well as energy consumption and GHG emissions - greenhouse gases;

- providing recycling waste opportunities and monitoring the amount of recycled waste.

All the above requirements have urged Moldovan manufacturers to look for costeffective methods to improve the industrial waste management and energy efficiency and minimize energy consumption and greenhouse gas emissions. 
Therefore, the basic purpose of the article is to address systemic solutions to help the management of the Moldovan apparel manufacturers to capitalize on their commitment towards the environment and generate credible evidence of compliance with all environmental laws, regulations, standards and due diligence requirements pursuing partnerships with famous clothing brand owners.

\section{Analysis of the Moldovan apparel manufacturers' economic activity}

In the Republic of Moldova, the economic activity "Apparel manufacturing" is a component part of the light industry sector. The light industry comprises three economic activities as follows: C13 Manufacture of textile, C14 Manufacture of wearing apparel and C15 Tanning and dressing of leather; manufacture of travel and leather goods, harness and footwear; preparation and dyeing of furs.
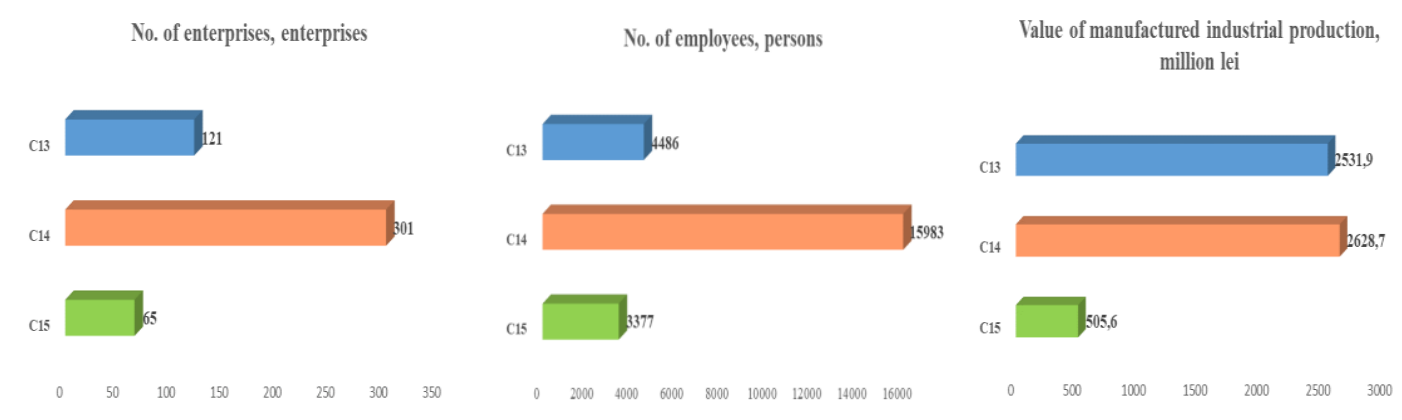

Figure 1. The structure of the light industry sector of the Republic of Moldova in 2019. Source: developed by the authors based on the data extracted from the National Bureau of Statistics of the Republic of Moldova www.statistica.md

The information presented in figure no.1 shows that in 2019 the activity C14 obtained the largest share in the light industry sector. This can be explained by the fact that the largest number of enterprises, and namely 301, were concentrated in this activity, employing an average number of 15,983 workers, and manufacturing a production volume worth 2628.7 million lei. In the next stage of the analysis we will proceed to the detailed synthesis of the activity of apparel manufacturers during the years 2014 - 2019. For this purpose, we generated the statistical data compiled in table no. 1 . According to the data presented in table no. 1 , the interest in manufacture of wearing apparel has registered an ascending increase within the last 6 years (the period between 2014-2019). Thus, we observe an increase in the value of manufactured industrial production during 2014-2019, from 1765.9 million lei in 2014 to 2628.7 million lei in 2019. The indices of the volume of industrial production show the same results, except for 2019, when the manufacture of wearing apparel registered a decrease of 6.5 percentage points compared to the previous year.

Table 1

\section{The main indicators of the economic activity C14 Manufacture of wearing apparel}

\begin{tabular}{llcccccc}
\hline \multicolumn{1}{c}{ Indicator } & $\mathbf{2 0 1 4}$ & $\mathbf{2 0 1 5}$ & $\mathbf{2 0 1 6}$ & $\mathbf{2 0 1 7}$ & $\mathbf{2 0 1 8}$ & $\mathbf{2 0 1 9}$ \\
\hline $\begin{array}{l}\text { 1. } \\
\begin{array}{l}\text { Value of the manufactured industrial } \\
\text { production, million lei }\end{array}\end{array}$ & 1765.9 & 1973.3 & 2257.2 & 2528.4 & 2653.4 & 2628.7 \\
\hline $\begin{array}{c}\text { 2. Indices of industrial production volume, \% } \\
\text { previous year=100 }\end{array}$ & 110.3 & 119.9 & 115.1 & 102.3 & 102.1 & 93.5 \\
\hline $\begin{array}{r}\text { 3. Indices of industrial production volume, \% } \\
\text { year 2010=100 }\end{array}$ & 131.2 & 158.4 & 182.8 & 186.2 & 189.5 & 176.4 \\
\hline
\end{tabular}


Continuation Table 1

\begin{tabular}{llcccccc}
\hline 4. & $\begin{array}{l}\text { The share (structure) of industrial } \\
\text { production, } \%\end{array}$ & 4.1 & 4.3 & 4.7 & 4.8 & 4.7 & 4.4 \\
\hline 5. & $\begin{array}{l}\text { Number of enterprises and production } \\
\text { units, enterprises }\end{array}$ & 240 & 253 & 255 & 267 & 285 & 301 \\
\hline 6. & Average number of employees, persons & 13,933 & 14,405 & 14,802 & 16,004 & 15,795 & 15,983 \\
\hline
\end{tabular}

Source: processed by the authors based on the data extracted from the National Bureau of Statistics of the Republic of Moldova www.statistica.md

The economic activity C14 has a share of about 5\% in the structure of industrial production. The increase registered was also generated by the increase in the number of enterprises from 240 in 2014 to 301 in 2019, which led to an increase in the average number of employees that amounted nearly 16,000 people in 2019.

Over $70 \%$ of the total value of the manufactured industrial production in the Republic of Moldova is export-oriented, as presented in the figure no. 2.

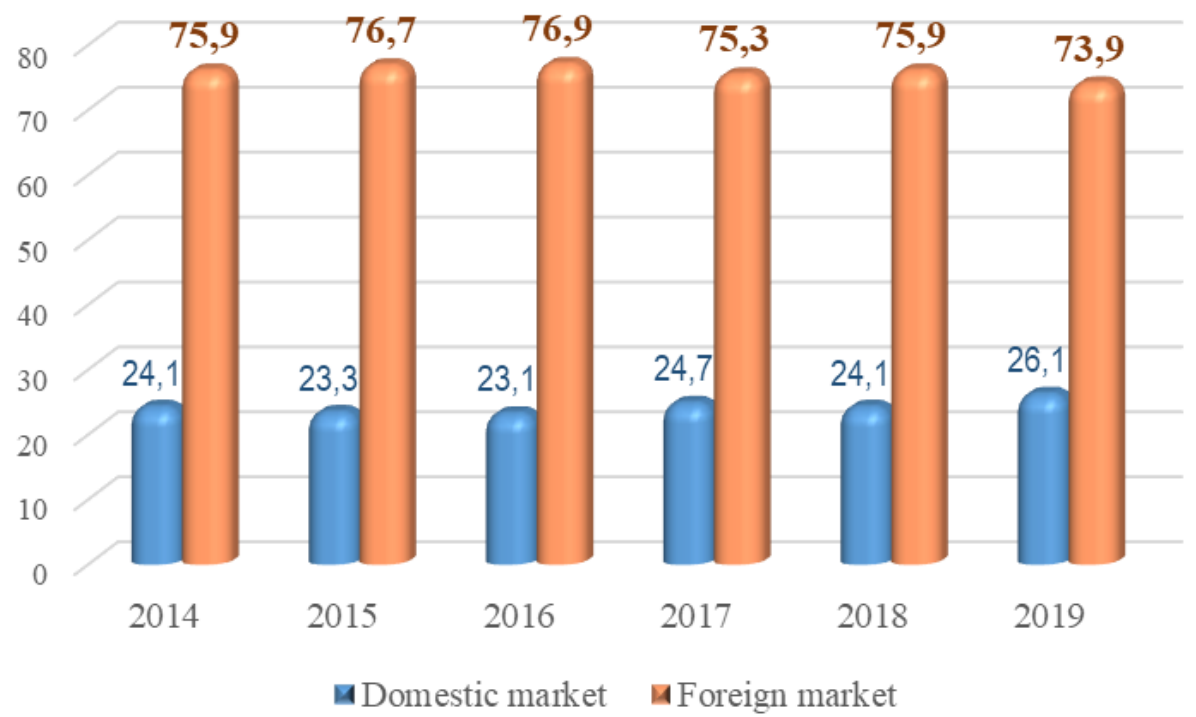

Figure 2. The structure of apparel markets, in \%.

Source: developed by the authors based on the data extracted from the National Bureau of Statistics of the Republic of Moldova www.statistica.md

The evolution of the market structure presented in figure no. 2 attests the business models adopted by apparel manufacturers within this activity, which are based on several international collaboration practices: CM, CMT, FOB, Private Label and Own Label:

- The inward processing customs regime "Cut \& Make" (CM) or "lohn" is a system that includes the production cycle: tailoring, sewing, moisture treatment and packaging.

- "Cut, Make \& Trim" (CMT) or "semilohn" is a more advanced system, which includes the production cycle, plus the supply of accessories and packaging (buttons, thread, cardboard boxes, labels, bags, plastic etc.).

- „Free on Board" (FOB) customs regime is when the foreign customer comes with the sample and places the order, while the goods are shipped by the manufacturer to the destination indicated by the client. In many cases, the customer indicates where the raw materials and accessories can be purchased from, and sometimes negotiates prices on behalf of the manufacturer.

- "Private Label" is the next stage, which involves the actual production, supply of raw materials, design, and the development of patterns. 
- "Own Label" is the stage when the company decides to carry out the production cycle, from product design up to the development, production, promotion, development of its own brand, marketing, sales, etc.

The manufactured production is exported mainly to countries from the European Union, including Italy, Germany, France, Belgium, Bulgaria, and Austria. This orientation also calls for Moldovan apparel manufacturers to align their production systems to the sustainable growth models adopted by the European Community. The development of ecological technologies is one of the main competitive advantages of the European Union, which demonstrates the relevance of researching the promotion of Moldovan apparel manufacturers' sustainable development.

\section{The topicality of industrial ecology}

The local apparel manufacturers' desire to establish partnerships with the European Union calls for special attention and concern for the environment for several reasons:

- The requirement of the foreign client, who places the order for processing the raw material to obtain the clothing articles. In the Republic of Moldova, there are already registered practices for the client to conduct the audit at his supplier, even before signing the cooperation agreements, both initial and subsequent. However, the process of signing the agreement is preceded by an assessment based on well-defined criteria, which contain a separate section on the assessment of the environmental commitment and the actions taken in this regard. Many apparel manufacturers miss the opportunity to work with a foreign partner due to a lack of evidence of compliance with environmental legal requirements, both local and regional.

- The legal requirement - all apparel manufacturers are required to complete the Environmental Authorization from stationary sources of pollution, which is issued by the Public Services Agency of the Republic of Moldova for a period of 5 years. In the most common cases, the impact of economic activity on air pollution includes stationary sources resulting from boiler operation and mobile sources, which include vehicle transport. A better implementation of the environmental legislation and policies at the national level will help ensure a stable regulatory framework for manufacturers.

- The Environmental Strategy for the period 2014-2023, approved by Government Decision no. 301 as of April 24, 2014. This is one of the most important policy documents in the field of environmental protection, which establishes the priority development directions in this field. The main goal of the strategy is to guarantee the population of the Republic of Moldova the right to a sustainable unpolluted and healthy environment, in alignment with economic development and social welfare. The general objective is to create an efficient environmental management system, which will contribute to the improvement of the quality of environmental factors and will ensure a clean, healthy, and sustainable natural environment for the population [3].

- The manifestation of the concern for the future generations - the economic, financial, and sanitary crises encountered by the apparel manufacturers from the Republic of Moldova confirm the fact that the production systems are not sustainable. The linear economic model - the transformation of raw materials into products that are used, consumed, and then discarded - generates not only accumulations of pollutants and waste, but also a global competition for natural resources. If the current trends continue, regardless of country and income level, future generations will be more 
likely to face extreme temperatures and weather events, leading to a decline in the number of species, a growing deficit of resources and more intense pollution.

- Integration of the Republic of Moldova in the European Union - the political vector of the Republic of Moldova's integration in the European Union imposed the alignment of the national legislation to the provisions of the European Union directives and the insurance of the sustainable development of the country by promoting the green economy. The "Environment" chapter of the Association Agreement provides concrete commitments and activities of the Government of the Republic of Moldova in the field of environmental protection, such as - the promotion of green economic development and eco-innovations.

- Low environmental awareness by the management of apparel manufacturers. Considering the above-mentioned facts about the compliance with environmental legislation and the approval of the Environmental Strategy, the Republic of Moldova has many reservations in terms of environmental awareness, both economically and socially. In this context, the apparel manufacturing management should demonstrate a deep understanding of the complexity of the environmental issues and their consequences, which will allow them to take more conscious decisions, improve their ecological intelligence and promote environmental policies within the society.

To sum up the above, the environmental issue can no longer be addressed separately from the manufacturer's economic issues. Global competitiveness and the increasing use of limited resources are leading to considerable economic change. The policy of the European economy strives towards transformations to produce more with less resources. That is why the sustainable development of enterprises is tightly linked to a responsible environmental management. This calls for regulations, incentives, and public procurement policies, which will promote production and consumption patterns that are compatible with the country's sustainable ecological development [4, p. 116].

\section{Sustainable development of apparel producers}

The concept of sustainable development with focus on our common future was launched during the presentation of the well-known "Brundtland Report" by the World Commission on Environment and Development. According to the report, sustainable development is the type of is a means of development that meets the needs of the present without compromising the ability of future generations to meet their own needs

A sustainable society is one where economic growth is compatible with planetary boundaries and fairly distributed among its citizens. Sustainable development is not a new concept for the contemporary society, who has broadly discussed it on the international stage in 1987.

As result of the growing importance and exacerbation of sustainable development issues, in 2000, in Friibergh (Sweden), was adopted the Statement on Sustainability Science, which aims to substantially improve the "interactions between nature and society", taking into account the unsustainable development path undertaken by the humanity in recent decades, as well as the need to reconcile the goals of social evolution with the long-term ecological limits of the planet, paying special attention to the way environmental changes affect society [5]. In September 2015, UN members reaffirmed that sustainable development is the way forward for both developed and developing countries.

Sustainability addresses the complexity, time gaps between economic and social actions and their consequences, the development of specific theories and semi-quantitative models, and the performance on three coordinates [6, p. 472]: 
1) On the economic level: increasing the degree of resource harnessing and eliminating the loss of renewable resources.

2) On the ecological level: avoiding environmental degradation.

3) On the socio-cultural plan: ensuring living conditions and human achievement.

On the ecological level, the state of the environment in the Republic of Moldova has worsened in the last decade in terms of $\mathrm{CO} 2$ emissions, drinking water quality and firewood consumption. The Government of the Republic of Moldova has identified climate change as a national priority and is approaching it from the perspective of gas emissions, as well as adaptation to climate change and risk management related to climate change. In this sense, the Government approved the Environmental Strategy for 2014-2023, which aims to integrate the principles of environmental protection and sustainable development, the development of the green economy and the adaptation to climate change in all sectors of the national economy [3].

The natural environment represents one of the basic elements of the national and international business environment. Insufficient resources and the phenomena generated by global climate changes call for manufacturers to pay special attention to the natural environment, to protect it and use it as responsibly and efficiently as possible.

The natural environment includes geographical and ecological factors that influence the economic activity. The company and its entire economic activity are part of its environment, the company being obliged to comply with environmental requirements.

The global pressure and environmental sustainability are forcing manufacturers to reconsider their business models. Consumers in both industrialized and developing countries have become aware of the importance of protecting the environment and are shifting towards environmentally friendly products and services. Some companies are pioneering sustainable innovation in the products and services they offer within their business, while others are adapting along the way. In any case, "green" products and services are benefitting from competitive advantages in the fight against competing products and services [7, p. 338].

The general objective of sustainable development is to find an optimal interaction between the four systems: economic, human, environmental, and technological, which are in a dynamic and flexible process of operation, to achieve the objectives. Under these conditions, achieving the goal of sustainable development requires major changes in economic and environmental policies, which will lead to a reduction in resource consumption per unit of useful effect [4].

Sustainability is a phenomenon that manifests itself as a result of the relationship generated by the economic and ecological systems, whereas human life can continue indefinitely as individuals prosper and human species develop with human activities staying within the limits, so as to avoid the destruction of the diversity, complexity and function of the environmental support system. Now, human society operates on the principle of indebtedness to future generations in terms of consumption and effects on the natural and global environment (including financial).

The sustainability process is based on the following components [7, p. 376 - 377]:

1) Connectivity - involves the existence of interdependent relationships between ecology, social structure, and economy. Sustainability is what can provide opportunities for growth by ensuring equitable access to resources and protection of the environment, universal health, and reproductive care.

2) Equity - highlights the need to develop a fair relationship between generations and species. From this point of view, sustainability is the result of respect for other individuals and even for life.

3) Security - supports the need to minimize threats and protects against destructive effects. Security actions are aimed at ensuring the health of the social system and natural capital. 
As the main actors of the business environment, companies must ensure together with the decision-making forums the climate of a good collaboration to use the natural resources efficiently and productively, to generate the necessary conditions for humanity. Ensuring good living conditions highly depends on the companies' level of participation, accountability, reciprocity, and transparency, including the fulfillment of basic criteria.

4) Prudence - emphasizes the requirement to concentrate all efforts to maintain a sustainable planet. This component shows how necessary it is to develop a strategy to maintain the planet as a safe area for all living creatures.

5) Inclusion - aims for human development in time and space. It refers to global environmental changes, determined by anthropogenic factors influenced by changes in population structure, economic growth or development, technological changes, political and economic organizations, mentality, and behaviors of all actors.

Apparel manufacturers must make a commitment towards future generations to pay special attention to the environment, in each phase of their activity [8].

The level of effort that each apparel manufacturer is willing to invest in sustainable development is highly dependent on the amount of benefits they can receive. They pursue advantages such as: brand consolidation, cost reductions or better risk management. In addition, most international apparel manufacturers are starting to prioritize social and environmental issues over traditional competitive advantages, including price or quality of services [9].

\section{Proposed environmental protection policies and strategies}

The apparel manufacturer's ability to achieve real sustainability depends on its environmental and social sensitivity. In other words, producers need to become eco-centric first and then focus on sustainability, all of which require a lot of effort and time. Environmental protection policies and strategies call for the involvement of top management representatives, who need to go beyond compliance and efficiency to avoid risks and minimize costs [10].

Many corporations list environmental protection activities as a priority for the long-term development strategy of their companies, ensuring increased efficiency, protection of nature and fulfillment of sustainability goals [5].

The ecological behavior of apparel manufacturers implies the integration of environmental issues in the strategic management process or in the environmental strategy [11].

In this context, we propose a set of environmental policies and strategies that can be effectively adopted and implemented by apparel manufacturers, such as:

- Introducing corporate ecology in the organizational culture. Corporate environmentalism is the process by which companies will address environmental issues and develop appropriate strategies to overcome them. Constant care for the conservation and protection of the natural environment improves the image of the manufacturer and facilitates the establishment of close relationships with customers and suppliers. This strategy is part of the company's identity, which shapes and strengthens the relationship between the company and the representatives of all stakeholders.

- Carrying out the environmental impact assessment of the apparel manufacturing activity. Environmental impact assessment is a tool to ensure the prevention or minimization of possible significant effects on the environment that may occur as a result of the development of the apparel manufacturers' industrial activities. It is recommended to determine the environmental aspects of its activities, the products and services that it can control and influence, as well as the associated environmental impacts, from the perspective of the product life cycle [12]. 
- Assuming the environmental commitment by approving the company's Environmental Policy. Environmental policy is a statement made by the company's top management that confirms the management's commitment to protect the environment, including pollution prevention and other commitments relevant to the business, which will strengthen the company's value. The formalization of the environmental policy will be a strong first step in ensuring the sustainable development of the enterprise [13].

- Developing and approving environmental strategies - which refer to the discovery, the implementation and the adoption of environmentally friendly technologies that are less harmful for the environment, the launch of environmentally friendly products, the creation of facilities to reduce waste and pollution, and the recognition of the environmental impact of the enterprise. The corporate environmental strategy is approached in three fundamental stages: pollution prevention, product management and sustainable development [7, p. 382].

- Integrating environmental strategies in the strategic management process - some activities supporting the reduction of the negative impact on the environment require additional investments in the modernization of technological equipment, as well as the implementation of good waste management practices. In this context, we consider important to include environmental objectives with the reservation of the necessary resources in documents outlining strategies, to ensure their good implementation and therefore the improvement of the environmental performance.

A reasonable solution, which would integrate the proposed policies and strategies would be to apply an environmental management system (EMS) based on ISO 14000 standards.

ISO 14001:2015 - the international standard for the design and implementation of an EMS, internationally recognized and accepted by most countries around the world provides a framework and guidelines for the creation and implementation of the EMS. The standard specifies the requirements for an organization to increase its environmental performance and manage its environmental responsibilities in a systematic manner that contributes to the environmental pillar of sustainability [14].

An environmental management system - consists of policies, processes, plans, practices and monitoring that define the rules governing the interaction of the enterprise with the environment.

Moldovan apparel manufacturers implementing EMS benefit from the following advantages [15]:

- a reduction in their "footprint" on the environment;

- better relationships with customers, the public and the community;

- the development of new business opportunities on markets where organic production processes are important;

- a reduction in production costs;

- a competitive advantage in social and environmental aspects;

- an improved image and increased credibility;

- the spread of an environmentally- responsible culture among their employees.

The application of the recommendations proposed in this article will ensure a sustainable competitive advantage for apparel manufacturing companies in the Republic of Moldova, which can be maintained for a long time. The competitive, sustainable advantage will enhance the sustainability, increasing the value of the enterprise, provided that it becomes an integral part of the overall sustainable strategy of the enterprise. 


\section{Conclusions}

The implementation of the sustainable strategies proposed in the article will contribute substantially to future challenges. It provides a comprehensive approach to the environment, laying the groundwork for a greener and more competitive economy that protects natural resources and the health of present and future generations. The article analyzed the priorities aimed at protecting the ecosystems of apparel manufacturers in the Republic of Moldova.

The analysis performed allowed the conclusion of the following remarks:

- apparel companies have a major share in the light industry sector of the Republic of Moldova, registering an upward growth during 2014 - 2019;

- the shift towards exports on foreign markets requires the adoption of a new model of economic development that fully integrates sustainability in all the strategies and operations conducted by the apparel companies;

- the sustainable development of apparel manufacturers is closely linked to the responsible management of the environment, which implies the reconsideration and transformation of the business models adopted;

- the company's focus on the environment, in each phase of its activity, must become a commitment for future generations;

- consumers have become aware of the importance of protecting the environment and are reorienting towards environmentally friendly products and services;

- the purchase of an item of clothing is an investment in the brand of the apparel manufacturer, and the investment that the consumer makes in a responsible brand allows the company that owns it to continue to contribute to sustainable development;

- a good solution for apparel manufacturers would be the implementation of an environmental management system based on the provisions of the ISO 14001: 2015 standard.

Moldovan apparel manufacturers that choose sustainable strategies and practices will obtain value as a result of increased revenues based on new orders from foreign partners, thus reducing costs through eco-efficiency, managing environmental risks and risks arising from strategic environmental strategies. They will also be able to transform intangible assets such as the image and reputation of the brand, and build collaborative networks with customers, competitors, and suppliers, all of which stimulate the process of sustainable development. Green products and technologies have a higher value, while an increased number of consumers favor apparel manufacturers that are implementing sustainable processes. The implementation of the proposals underscored by the authors in this article will ensure that the population of the Republic of Moldova lives in a safe and healthy environment, managed in a way that respects limits and ensures ecological resilience.

\section{Bibliographical references:}

1. Bruyninckx H. Un mediu sănătos este indispensabil pentru o economie durabilă și o societate echitabilă [online]. [accesat 20.11.2020]. Disponibil: https://www.eea.europa.eu/ro/articles/un-mediu-sanatos-este-indispensabil

2. Adaptarea agendei 2030 de dezvoltarea durabilă la contextul Republicii Moldova. Raport elaborat în cadrul proiectului „Naționalizarea Agendei de Dezvoltare Durabilă în contextul Republicii Moldova”, implementat de PNUD, cu suportul echipei de ţară a Naţiunilor Unite, inclusiv UNFPA, UNICEF, ILO și UN Women, Chișinău, 2017.

3. Strategia de mediu pentru anii 2014-2023 şi a Planului de acţiuni pentru implementarea acesteia. Aprobată prin Hotărârea Guvernului nr. 301 din 24.04.2014.

4. Mediu de afaceri favorabil pentru întreprinderi durabile în Republica Moldova. Organizaţia Internaţională a Muncii 2019, Publicat pentru prima dată în 2019 [online]. [accesat 17.11.2020]. Disponibil: https://www.ilo.org/wcmsp5/groups/public/---ed_emp/---emp_ent/documents/publication/wcms_736671.pdf 
5. SIM, Elena-Simina, VIOREL, Dan. Managementul riscului de mediu şi sustenabilitatea întreprinderii. Materialele publicate în cadrul conferinței a XI-a Conferința Națională multidisciplinară - cu participarea internațională, „Profesorul Dorin PAVEL - fondatorul hidroenergeticii românești”, Sebeș, 2011, pp. 435-444.

6. Jaba O. Managementul producției și operațiunilor. Iași, Ed. Sedcom Libris, 2007.

7. Marinoiu A.-M., Popescu I. -A.. Sustenabilitatea și inovarea în mediul international de afaceri. București, Ed. ASE, 2019.

8. Barbuta R., Hentea M., Mesteru S. Doina, Cociorvei D. STUDIUL: Rolul Consiliilor Economice si Sociale si al institutiilor similare din UE in promovarea conceptului de Responsabilitate Sociala a Companiilor. [online]. [accesat 179.2020]. Disponibil: https://www.ces.ro/newlib/studii-ces/STUDIUL-Responsabilitate-SocialaCompanii.pdf

9. Danciu V. Întreprinderea sustenabilă. Noi provocări și strategii pentru îmbunătățirea sustenabilității corporative. Articol publicat în Revista Economie teoretică şi aplicată Volumul XX (2013), No. 9(586), pp. 4-24.

10. Republic of Moldova-United Nations Partnership Framework for Sustainable Development 2018-2022. [online]. [accesat 15.11.2020]. Disponibil: https://www.md.undp.org

11. Suciu R. Studiu privind managementul de mediu al companiilor din România în contextul dezvoltării durabile. Articol publicat în Revista Transilvană de Ştiinţe Administrative 2 (37)/2015, pp. 197-214.

12. Punga I., Iordanov I. - R. Evaluarea impactului asupra mediului: Studiu de caz. Chişinău, 2016.

13. Europe's approach to implementing the Sustainable Development Goals: good practices and the way forward, Policy Department, Directorate-General for External Policies. STUDY. EP/EXPO/B/DEVE/2018/01 EN February 2019 - PE 603.473.

14. Standardul SM SR EN ISO 14001:2016. Sisteme de management de mediu. Cerințe și ghid de utilizare.

15. Comanescu M. Creşterea responsabilităţii faţă de mediu. Articol publicat în Revista Economie teoretică şi aplicată Volumul XVII (2010), No. 5(546), pp. 39 - 52.

\section{Electronic statistical databases:}

www.statistica.md wWw.madrm.gov.md www.mediu.gov.md www.legis.md www.asp.gov.md 